\title{
Microencapsulation and tissue engineering as an alternative treatment of diabetes
}

\section{S.S. M aria-Engler ${ }^{1}$, M. Mares-Guia2,3, M.L.C. Correa ${ }^{1}$ E.M.C. Oliveira ${ }^{1}$, C.A.M. Aita ${ }^{1}$, K. Krogh $^{1}$, M. Ribeiro ${ }^{2}$, L. Vilela ${ }^{3}$, I.L. N oronha ${ }^{4}$, F.G. Eliaschewitz ${ }^{5}$ and M.C. Sogayar ${ }^{1}$} T. Genzini ${ }^{4}$, M.P. Miranda ${ }^{4}$,

\author{
IInstituto de Q uímica, Universidade de São Paulo, \\ São Paulo, SP, Brasil \\ 2Diabetes Research Institute, University of Miami, \\ Miami, FL, USA \\ ${ }^{3}$ Biobrás S.A., M ontes Claros, M G, Brasil \\ ${ }^{4} \mathrm{H}$ ospital Beneficência Portuguesa and ${ }^{5} \mathrm{H}$ ospital Heliópolis, \\ São Paulo, SP, Brasil
}

\section{Correspondence \\ M.C. Sogayar \\ Instituto de Química \\ Universidade de São Paulo \\ Caixa Postal 26077 \\ 05513-970 São Paulo, SP \\ Brasil \\ E-mail: mcsoga@iq.usp.br \\ Presented at \\ SIMEC 2000 - International \\ Symposium on Extracellular \\ Matrix, Angra dos Reis, RJ, \\ Brazil, September 24-27, 2000. \\ Research supported by FAPESP, CNPq, ICGEB, PRP-USP and Biobrás S.A.}

Received October 23, 2000 Accepted March 6, 2001

\section{Abstract}

In the 70's, pancreatic islet transplantation arose as an attractive alternative to restore normoglycemia; however, the scarcity of donors and difficulties with allotransplants, even under immunosuppressive treatment, greatly hampered the use of this alternative. Several materials and devices have been developed to circumvent the problem of islet rejection by the recipient, but, so far, none has proved to be totally effective. A major barrier to transpose is the highly organized islet architecture and its physical and chemical setting in the pancreatic parenchyma. In order to tackle this problem, we assembled a multidisciplinary team that has been working towards setting up the Human Pancreatic Islets Unit at the Chemistry Institute of the University of São Paulo, to collect and process pancreas from human donors, upon consent, in order to produce purified, viable and functional islets to be used in transplants. Collaboration with the private enterprise has allowed access to the latest developed biomaterials for islet encapsulation and immunoisolation. Reasoning that the natural islet microenvironment should be mimicked for optimum viability and function, we set out to isolate extracellular matrix components from human pancreas, not only for analytical purposes, but also to be used as supplementary components of encapsulating materials. A protocol was designed to routinely culture different pancreatic tissues (islets, parenchyma and ducts) in the presence of several pancreatic extracellular matrix components and peptide growth factors to enrich the beta cell population in vitro before transplantation into patients. In addition to representing a therapeutic promise, this initiative is an example of productive partnership between the medical and scientific sectors of the university and private enterprises.

\section{Key words}

- Human pancreatic islets

- Pancreas

- Extracellular matrix

- Stem cells

- Islet microencapsulation

- Transplantation

- Ductal cells 
Whole organ pancreas transplant, which involves a major and risky surgery, restores normal glucose control of insulin secretion, but is restricted to patients with pancreatitis, renal failure or very labile diabetes, who will then require strong immunosuppression. The advent of insulin therapy in the 20's rescued diabetic patients from a life-threatening situation. However, in order to prevent numerous complications (vascular, renal and ocular failure) arising from this disease, a rigorous schedule of insulin administration is required, affecting the rate of patient compliance with treatment and causing occasional and dangerous episodes of hypoglycemia. Only whole pancreas and islet transplantation are capable of permanently reversing the hyperglycemic state and preventing or delaying at least some of the secondary complications of the disease (1-3). Upon re-vascularization, the transplanted whole pancreas is immediately capable of secreting insulin (4). However, whole pancreas transplantation constitutes a delicate surgical procedure requiring intense and continuous immunosuppressive therapy, that should be used exclusively in patients requiring simultaneous transplant of other organs like kidney, liver, etc. or in some patients with unmanageable diabetes (4-6).

Islet transplantation has the potential to become a widely applicable treatment for insulin-dependent diabetes. The main advantage of this procedure over whole organ transplantation is the fact that islets may be implanted in a relatively small volume into the portal vein, a much easier procedure which eliminates operative risks and postoperative morbidity $(7,8)$. Shapiro et al. (8) were recently responsible for a major breakthrough in this field, introducing the socalled Edmonton Protocol, a procedure for pancreatic islet transplantation applied to seven diabetic patients who showed sustained insulin independence for over a year after transplantation. The success of this procedure was based on a glucocorticoid-free immunosuppressive therapy, thus eliminating the use of diabetogenic drugs, and also on the use of a high number of transplanted islets per patient.

One of the main obstacles to successful islet transplantation for both type 1 and 2 diabetes and to reproduce the Edmonton Protocol is the limitation of insulin-producing tissue (9). Only about 3,000 cadaver pancreases become available in the US each year, while about 35,000 new cases of type 1 diabetes are diagnosed each year (10).

The islets of Langerhans comprising the endocrine pancreas represent only 1 to $2 \%$ of the total pancreas mass and are dispersed throughout the exocrine pancreas. In order to obtain purified islet preparations (see Figure 1), the organ is subjected to special procedures of digestion with collagenase and purification in density gradients. However, the total number of islets obtained from a human pancreas is lower than the total islet content due to several variables that affect the final yield in human islet isolation procedures. In addition to the intrinsic variability of islet number within the native pancreata, several variables related to donor characteristics and to the islet isolation procedure may further affect the islet yield. Donor variables include age, gender, body mass index, diet, trauma, hypoxia or ischemic conditions (11). Pancreatic architecture, composition of Clostridium histolyticum collagenase preparations, endotoxicity, digestion time and cold ischemic time are some of the variables related to the islet purification procedure (12).

All of these variables are responsible for the lack of an adequate islet supply, leading to concentrated efforts to stimulate the growth of new pancreatic islet tissue in vitro (9). Alternatives to the stimulation of active proliferation and functional islets in vitro are based on cell culture strategies, namely the use of extracellular matrix (ECM) elements as substrates to culture isolated islets and ductal or stem cells.

The proliferative potential of stem and 
ductal cells is due to the characteristics of pancreas ontogeny, since apparently islet development is initiated from stem cells that are associated with the pancreatic ductal epithelium, which differentiates into the various islet-associated endocrine cell populations (13-15). Thus, it is generally accepted that all endocrine cell types of pancreatic islets (glucagon-producing $\alpha$ cells, insulinproducing $\beta$ cells, somatostatin-producing $\delta$ cells and pancreatic polypeptide-producing PP cells) arise from the same ductal epithelial stem cell through sequential differentiation $(16,17)$. Pancreatic islets are organized into spheroid structures in which $\beta$ cells form a core surrounded by a mantle of $\alpha$ cells, interdigitating $\delta$ cells and PP cells (16,18-20). Immature spheroid islet-like structures bud from the ductal epithelium and migrate short distances into the surrounding acinar tissue, where angiogenesis occurs, allowing direct arteriolar blood flow into mature islets (18).

The final stage of phenotypic expression and cellular differentiation may, in fact, be controlled by the proximity of cells to a local stimulus originating in the pancreas itself
$(21,22)$. In this regard, the role of cell-cell and cell-ECM interactions in pancreatic $\beta$ cell development and differentiation appears to be of particular importance (23-26). Possible mechanisms of action include secretion of a proliferation/differentiation-inducing factor, information exchange through cell-cell contact, and production of ECM containing a critical trophic factor.

To a greater or lesser extent, all types of cellular transplants involve disruption of cellular connections (cytoskeleton) to the ECM (27). Tissue culture techniques have already demonstrated that these disruptions may compromise cell viability and function (28). It is still controversial whether a high degree of islet purification is really necessary or advantageous. A certain degree of acinar and ductal contamination could be desirable if one considers the potential for $\beta$ cell neogenesis from ductal cell $(11,13)$.

Maintenance of the ECM seems to be a highly critical factor; however, enzymatic digestion is poorly controlled during islet isolation and therefore not only is the interstitial matrix destroyed, but the peri-insular basement membrane may be readily digested

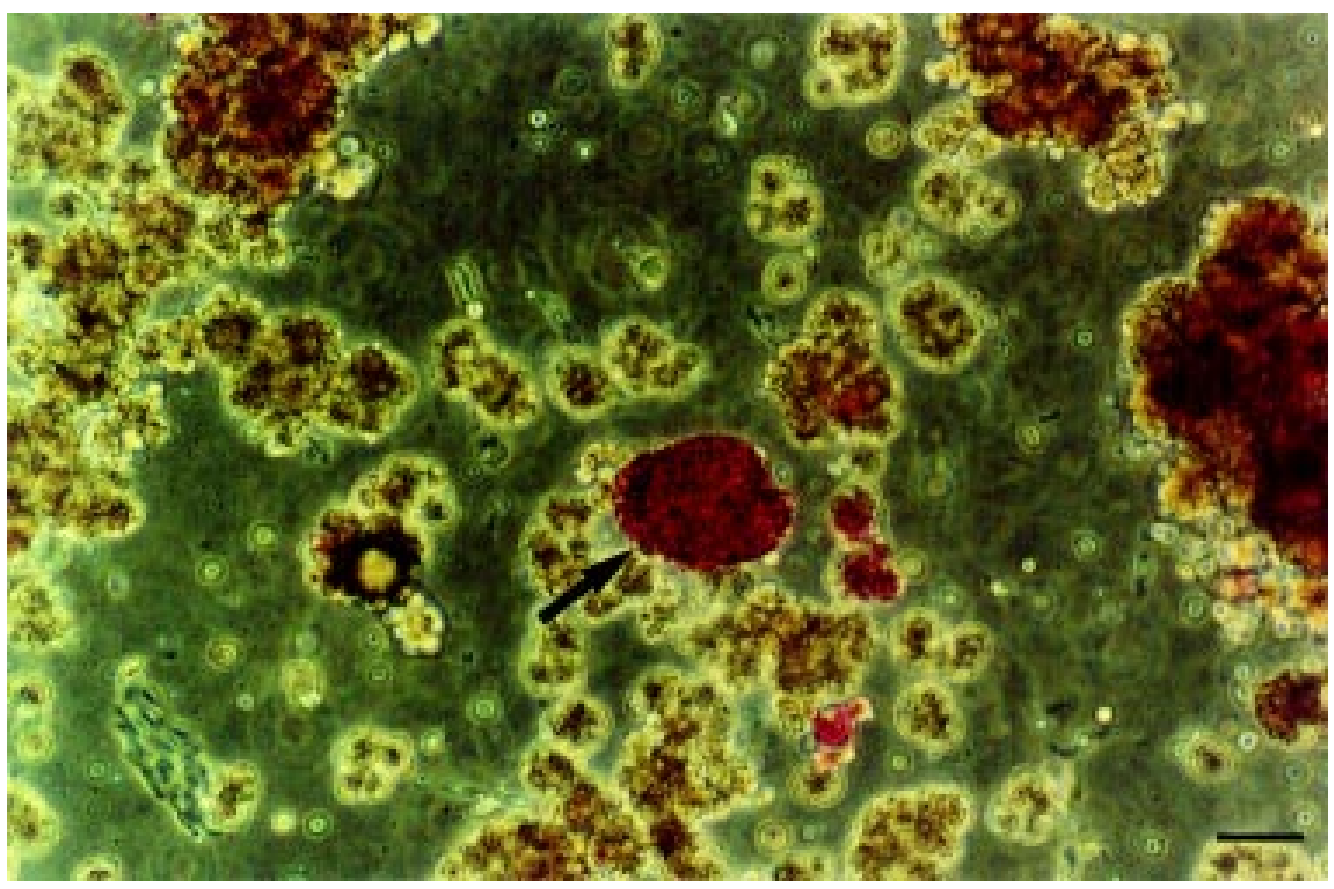

Figure 1. Human pancreatic islets (arrow) during the purification procedure, stained with dithizone, which specifically binds to zinc present in \& cell insulin granules. Bar: $100 \mu \mathrm{m}$. 
as well (29). The ECM is the most important component of the islet microenvironment. It is a dynamic complex of different molecules that functions as a cellular scaffold, which also regulates both cell differentiation and survival. ECM is found in two forms, namely, interstitial matrix and basement membrane. The pancreatic islet basement membrane is composed of collagen IV, laminin and fibronectin (12). Disruption of islet cell-matrix interactions (30-32) and loss of the basement membrane lead to induction of apoptosis $(33,34)$. According to Thomas et al. (28), islets embedded in the ECM during the isolation procedure display a low apoptotic rate in culture when compared to highly purified islet preparations.

In virtually all types of cellular transplants, isolation of cells or tissues (islets, hepatocytes, nervous tissue, etc.) involves some degree of disruption of cell-ECM connections, which are maintained, primarily, by integrins. Incomplete islet digestion, leaving an outer ring of ECM and, hopefully, preventing the induction of transmembrane integrin signaling, is another strategy that may prevent apoptosis (35).
The importance of the ECM substrate to induce differentiation was reported by several laboratories. Thivolet et al. (36) suggested that ECM markedly enhances islet cell attachment and proliferation, as well as long-term maintenance in culture. Perfetti et al. (37) suggested the trophic effect of Matrigel on maintenance of normal $\beta$ cell activity and function. Rat $\beta$ cell islets cultured for 6 weeks on Matrigel showed an equal number of insulin-secreting cells and increased levels of insulin mRNA compared to freshly isolated islets cultured for only 3 days in the absence of Matrigel. Hayek et al. (38) pioneered the work showing that human B cells grown in monolayer culture are able to replicate when exposed to selected matrices and growth factors. Recently, BonnerWeir et al. (10) described the expansion of human ductal tissue in vitro and its subsequent differentiation into islet cells after being overlaid with Matrigel. Over a period of 3-4 weeks there was a significant increase in insulin as well as formation of islet-like structures that were called cultivated human islet buds.

The ability to cultivate human islets in
Figure 2. Biodritin capsules of $400-600 \mu \mathrm{m}$ in diameter. Magnification $40 \mathrm{X}$.

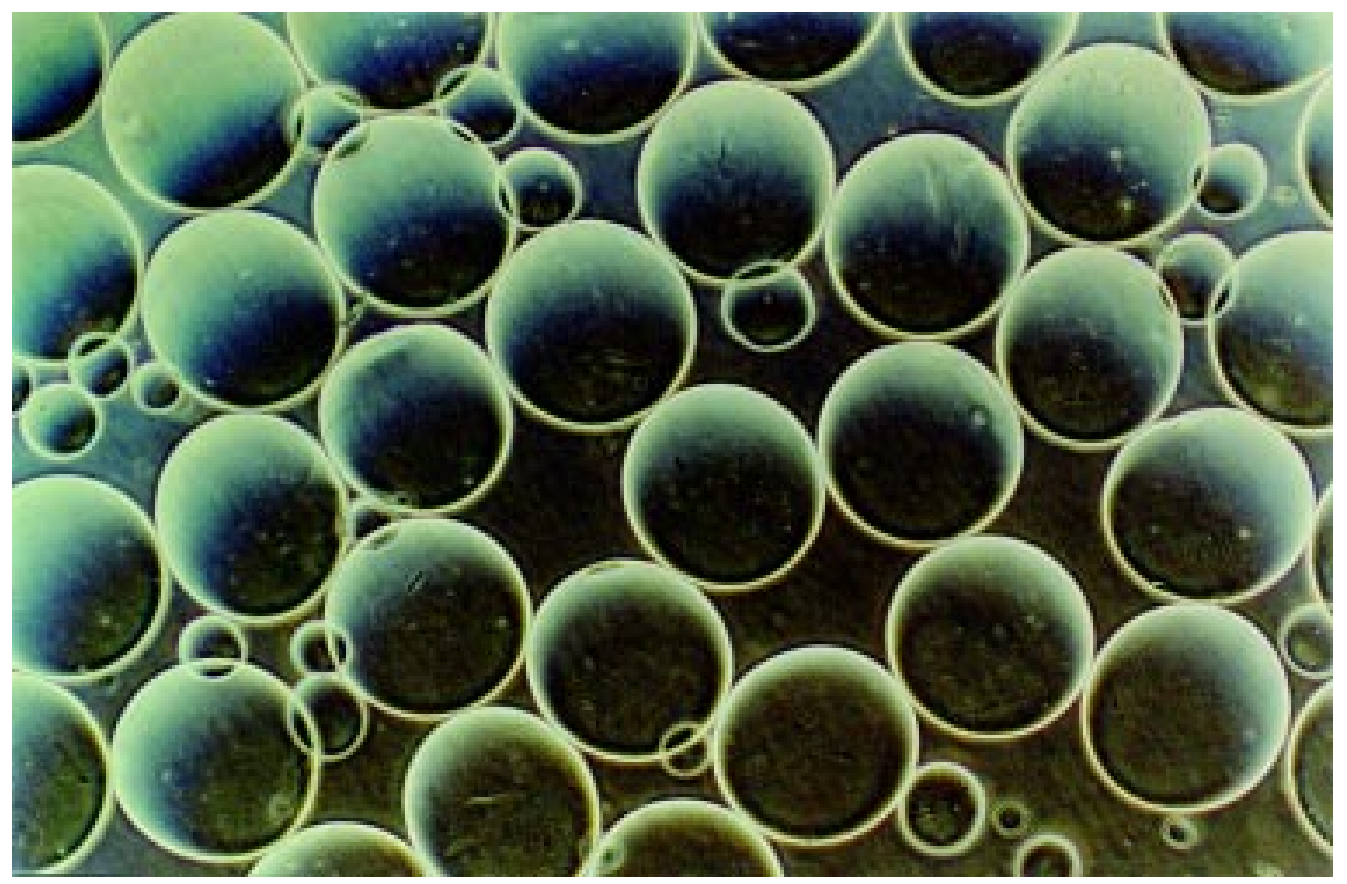


vitro from digested pancreatic tissue, which is usually discarded after the islet isolation procedure, opens a new approach for $\beta$ cell replacement therapy (10). Since human islet isolation yields, at best, only 400,000600,000 islets, more than one donor may be required for a successful transplant (10).

Despite the success of the newly introduced immunosuppressive therapeutic scheme in islet transplantation (8), the idea of creating a physical barrier between transplanted islet tissue and the host would aim at graft immunoprotection and provide an artificial, three-dimensional architecture which may attenuate the impact of potentially noxious environmental factors on newly transplanted islet cells $(27,39)$.

The major obstacles to successful microencapsulated islet transplantation are related to deficient nutrient diffusion, local fibrosis and the use of inadequate material for the capsules, thus compromising biocompatibility. Islets to be implanted should be homogeneously dispersed inside the capsules in order to maximize oxygen and nutrient diffusion (39-41).

Fabrication of microcapsules surround- ing individual islets or small islet clusters represents a very delicate procedure. The procedure consists of enveloping the islet cells within homogenous and semi-permeable artificial membranes without affecting tissue morphologic integrity or functional competence, aiming at protecting the graft from rejection in the absence of immunosuppressive therapy (42). Thus, the membrane should be permeable to insulin and low molecular weight components such as oxygen, glucose, electrolytes and other nutrients and impermeable to lymphocytes and other cellular components of the immune system and also to antibodies, cytokines and other mediators of the immune response (43-45).

The microcapsules consist of polymer spheres of 400-800 $\mu \mathrm{m}$ in diameter, made of the polysaccharide alginate. Semi-automatic production is required due to the need for microcapsules of homogeneous shape $(42,43$, 46-54). Several studies have shown that alginate-microencapsulated islets maintain cell viability and functional activity even in longterm culture (42). The euglycemic state resumes and rejection is avoided in diabetic animal models subjected to both allo- and

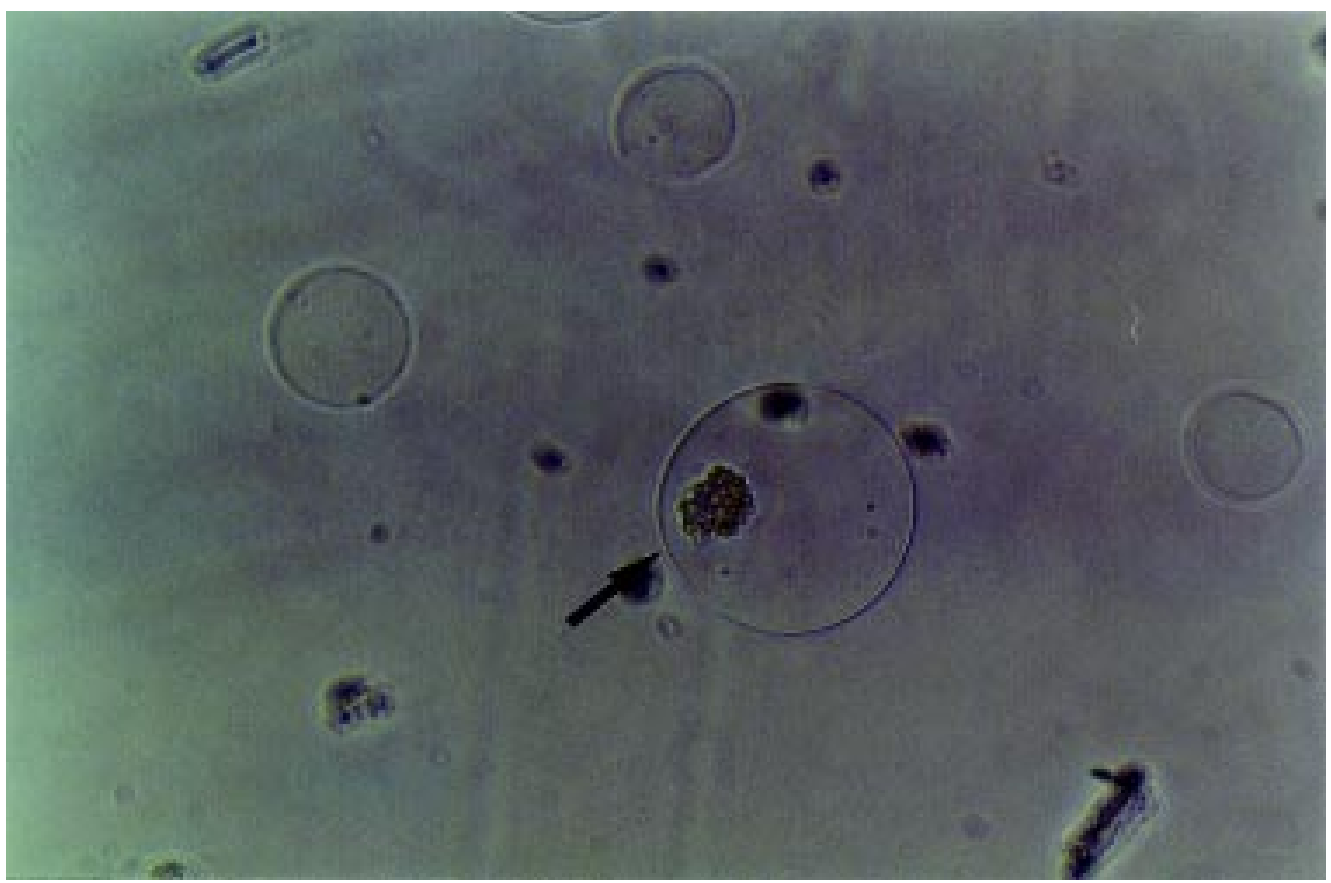

Figure 3. Biodritin capsule of $400 \mu \mathrm{m}$ in diameter (arrow) containing a human pancreatic islet. Magnification 100X. 
xenotransplant $(42,47-54)$. Using microencapsulated porcine islets transplanted into the peritoneal cavity of primates, Sun and colleagues (52) observed the efficacy of longterm diabetes reversal in the absence of immunosuppressive therapy.

This technology has been optimized for human use by attempting to reduce the alginate/polyamino acid capsule size to $350-400$ $\mu \mathrm{m}$ in diameter and to reach high selectivity and stable composition in order to allow implant into the spleen and kidney parenchyma (54).

Recently, Mares-Guia and Ricordi (55) have reported the discovery of Biodritin, a new heteropolysaccharide resulting from conjugation of alginate and chondroitin sulfate, a material that is more biocompatible than other previously described materials. Biodritin has been used to prepare Biodritin-
poly-L-lysine microcapsules at the Diabetes Research Institute, University of Miami, Miami, FL, USA, and at the Human Pancreatic Islets Unit of the Chemistry Institute, University of São Paulo, São Paulo, SP, Brazil (Figures 2 and 3).

Results obtained in experimental alloand xenotransplants (42,47-54), along with the discovery of new materials to compose microcapsules (55) and the possibility of maintaining islet homeostasis with ECM components suggested here, may point to a new era in diabetes therapy.

\section{Acknowledgments}

The authors are deeply grateful to the donors and their families for making this research possible.

\section{References}

1. Orloff MJ , Macedo C, Macedo A \& Greenleaf GE (1987). Comparison of whole pancreas and pancreatic islet transplantation in controlling nephropathy and metabolic disorders of diabetes. Annual Surgery, 206: 324-334.

2. Orloff MJ, Macedo A \& Greenleaf GE (1988). Effect of pancreas transplantation on diabetic somatic neuropathy. Surgery, 104: 437-444.

3. Hering BJ , Bretzel RG, Hopt UT, Brandhorst $H$, Brandhorst $D$, Bollen CC, Raptis G, Helf F, Grossmann R \& Mellert J (1994). New protocol toward prevention of early human islet allograft failure. Transplantation Proceedings, 26: 570-571.

4. Oberholzer J , Triponez F, Lou J \& Morel P (1999). Clinical islet transplantation: a review. Annals of the New York Academy of Sciences, 875: 189-199.

5. London NJ M, Robertson GSM, Chadivick DR, J ohnson PRV, J ames RFL \& Bell PRF (1997). Human pancreatic islet isolation and transplantation. Clinical Transplantation, 8: 421-459.

6. Secchi A, Di Carlo V \& Pozza G (1997). Pancreas and islets transplantation: Current progress and perspectives. Hormone and Metabolic Research, 29: 1-8.

7. Ricordi C \& Hering BJ (1988). Human islet allotransplantation. Current Opinion in Organ Transplantation, 3: 274-278.

8. Shapiro AM, Lakey J RT, Ryan EA, Korbutt GS, Toth E, Warnock GL, Kneteman NM \& Rajotte RV (2000). Islet transplantation in seven patients with type 1 diabetes mellitus using a glucocorticoid-free immunosuppressive regimen. New England J ournal of Medicine, 343: 230-238.

9. Zwillich T (2000). Islet transplants not yet ready for prime time. Science, 289: 531533.

10. Bonner-Weir S, Taneja M, Weir GC, Tatarkiewicks K, Song KH, Sharma A \& O'Neil JJ (2000). In vitro cultivation of human islets from expanded ductal tissue. Proceedings of the National Academy of Sciences, USA, 97: 7999-8004.

11. Ricordi C \& Hering BJ (2001). Pancreas and islet transplantation. Current Review of Diabetes (in press).

12. Van Deijnen J HM, Van Suylichem GHJ, Wolters GHJ \& Van Schilfgaarde R (1994). Distribution of collagens type I, type III and type $V$ in the pancreas of rat, dog, pig and man. Cell and Tissue Research, 277: 115-121.

13. Bonner-Weir S \& Smith FE (1994). Islet cell growth and the growth factor involved. Trends in Endocrinology and Me- tabolism, 5: 60-64.

14. J iang FX, Cram DS, De Aizpurua HJ \& Harrison LC (1999). Laminin-1 promotes differentiation of fetal mouse pancreatic beta-cells. Diabetes, 48: 722-730.

15. Slack J MW (1995). Developmental biology of the pancreas. Development, 121: 1569-1580.

16. Gu D \& Sarvetnick N (1993). Epithelial cell proliferation and islet neogenesis in IFN- $\gamma$ transgenic mice. Development, 118: 3346.

17. Hellerström C (1984). The life story of the pancreatic B cell. Diabetologia, 26: 393400.

18. Bonner-Weir S \& Orci L (1982). New perspectives on the microvasculature of the islets of Langerhans in the rat. Diabetes, 41: 93-97.

19. Weir GC \& Bonner-Weir S (1990). Islets of Langerhans: the puzzle of intraislet interactions and their relevance to diabetes. J ournal of Clinical Investigation, 85: 983987.

20. Teitelman G, Alpert S, PolakJ M, Martinez A \& Hanahan D (1993). Precursor cells of mouse endocrine pancreas coexpress insulin, glucagon and the neuronal proteins tyrosine hydroxylase and neuropeptide $Y$, but not pancreatic polypeptide. Develop- 
ment, 118: 1031-1039.

21. Fell PE \& Grobstein C (1968). The influence of extra-epithelial factors on the growth of embryonic mouse pancreatic epithelium. Experimental Cell Research, 53: 301-304.

22. Crick $F$ (1970). Diffusion in embryogenesis. Nature, 5231: 420-422.

23. Pictet RL \& Rutter WJ (1972). Development of the embryonic endocrine pancreas. In: Steines DF \& Freinkell N (Editors), Handbook of Physiology. Section 7. Vol. 1. American Physiological Society, Baltimore, MD, 25-66.

24. Spooner BS, Cohen HI \& FaubionJ (1977). Development of the embryonic mammalian pancreas: the relationship between morphogenesis and cyto-differentiation. Developmental Biology, 61: 119-130.

25. Montesano $R$, Mouron $P$, Amherdt $M \&$ Orci L (1983). Collagen matrix promotes reorganization of pancreatic endocrine cell monolayers into islet-like organoids. J ournal of Cell Biology, 97: 935-939.

26. Dudek RW, Lawrence IE, Hill RS \& J ohnson RC (1991). Induction of islet cytodifferentiation by fetal mesenchyme in adult pancreatic ductal epithelium. Diabetes, 40: 1041-1048.

27. Ricordi C \& Rastellini C (1995). Automated method for pancreatic islets separation. In: Ricordi C (Editor), Methods in Cell Transplantation. RG Landes Company, Austin, 433-438.

28. Thomas FT, Contreras J L, Bilbao G, Ricordi C, Curiel D \& Thomas J M (1999). Anoikis, extracellular matrix, and apoptosis factors in isolated cell transplantation. Surgery, 126: 209-304.

29. Wang RN \& Rosenberg L (1999). Maintenance of beta-cell function and survival following islet isolation requires re-establishment of the islet-matrix relationship. J ournal of Endocrinology, 163: 181-190.

30. Frisch SM \& Francis H (1994). Disruption of epithelial cell-matrix interactions induces apoptosis. J ournal of Cell Biology, 124: 619-629.

31. Beattie GM, Leibowitz G, Lopez AD, Levine $F \&$ Hayek A (2000). Protection from cell death in cultured human fetal pancreatic cells. Cell Transplantation, 9: 431-438.

32. Schwartz SM \& Bennett MR (1995). Death by any other name. American J ournal of Pathology, 147: 229-234.

33. Raff MC (1992). Social controls on cell survival and cell death. Nature, 356: 397400.

34. Meredith J EJ , Fazeli B \& Schwartz MA
(1993). The extracellular matrix as a cell survival factor. Molecular Biology of the Cell, 4: 953-961.

35. Ricordi $\mathrm{C}$, Alejandro R, Rilo $\mathrm{HH}$, Carroll PB, Tzakis AG, Starzl TE \& Mintz DH (1995). Long-term in vivo function of human mantled islets obtained by incomplete pancreatic dissociation and purification. Transplantation Proceedings, 27: 3382.

36. Thivolet $\mathrm{CH}$, Chatelain $\mathrm{P}$, Nicoloso $\mathrm{H}$, Durand A \& Bertrand J (1985). Morphology and function effects of extracellular matrix on pancreatic islets cell cultures. Experimental Cell Research, 159: 313322.

37. Perfetti $R$, Henderson TE, Wang $Y$, Monrose-Rafizadeh C \& Egan J M (1996). Insulin release and insulin mRNA levels in rat islets of Langerhans cultured on extracellular matrix. Pancreas, 13: 47-54.

38. Hayek A, Beattie GM, Cirulli V, Lopez D, Ricordi C \& Rubin J S (1995). Growth factor/matrix induced proliferation of human adult beta cells. Diabetes, 44: 1458-1460.

39. Inoue $K \& \&$ Miyamoto MJ (2000). Islet transplantation. J ournal of Hepato-BiliaryPancreatic Surgery, 7: 163-177.

40. Fraker C, Inverardi L, Ricordi C \& Bartlett R (2001). Islet immunoisolation. In: Gill R, Harmon J \& MacLaren N (Editors), Mediated Endocrine Diseases. Martini L, Modern Endocrinology Series (in press).

41. Ribeiro MM (1999). Estudo sobre a permeabilidade de microcápsulas de Biodritin a proteínas: A importância da carga nítida da proteína. Master's thesis, Departamento de Biologia Celular, Instituto de Ciências Biológicas, Universidade de Brasília, Brasília, DF, Brazil, 4-10.

42. Calafiore R \& Basta G (1995). Microencapsulation of pancreatic islets: Theoretical principles, technologies and practice. In: Ricordi C (Editor), Methods in Cell Transplantation. RG Landes Company, Austin, 587-609.

43. Calafiore R (1997). Perspectives in pancreatic and islet cell transplantation for the therapy of IDDM. Diabetes Care, 20: 889-896.

44. Lanza RP, Butler DH, Borland KM, Taruk JE, Faustman DL, Solomon BA, Muller TE, Rupp RG, Maki T, Monaco AP \& Chick WL (1991). Xenotransplantation of canine, bovine, and porcine islets in diabetic rats without immunosuppression. Proceedings of the National Academy of Sciences, USA, 88: 11100-11104.

45. Lanza RP, Solomon BA \& Chick WL (1995). Hollow fibers and macroencapsu- lation. In: Ricordi C (Editor), Methods in Cell Transplantation. RG Landes Company, Austin, 611-615.

46. Lim F \& Sun AM (1980). Microencapsulated islets as bioartificial endocrine pancreas. Science, 210: 908-910.

47. O'Shea GM \& Sun AM (1986). Encapsulation of rat islets of Langerhans prolongs xenograft survival in diabetic mice. Diabetes, 35: 943-946.

48. Fan MY, Lum ZP, Fu XW, Levesque L, Tai IT \& Sun AM (1990). Reversal of diabetes in BB rats by transplantation of encapsulated pancreatic islets. Diabetes, 39: 519522.

49. Fritschy WM, Strubbe J H, Wolters GHJ \& Van Schilfgaarde R (1991). Glucose tolerance and plasma insulin response to intravenous glucose infusion and test meal in rats with microencapsulated islet allografts. Diabetologia, 34: 542-547.

50. Krestow M, Lum ZP, Tai IT \& Sun AM (1991). Xenotransplantation of microencapsulated fetal rat islets in diabetic mice. Transplantation, 51: 651-655.

51. Lum ZP, Krestow M, Tai IT, Vacek I \& Sun AM (1992). Xenografts of rat islets into diabetic mice. Transplantation, 53: 11801183.

52. Sun $Y$, Ma X, Zhou D, Vacek I \& Sun AM (1996). Normalization of diabetes in spontaneously diabetic cynomologus monkeys by xenografts of microencapsulated porcine islets without immunosuppression. J ournal of Clinical Investigation, 98: 14171422

53. Sandler S, Andersson A, Eizirik DL, Hellerström C, Espevik T, Kulseng B, Thu B, Piperleers DG \& Skjak-Braek G (1997). Assessment of insulin in vitro from microencapsulated fetal porcine islet-like cell clusters and rat, mouse, and human pancreatic islets. Transplantation, 63: 17121717.

54. Calafiore R, Basta G, Luca G, Gialetti R, M oriconi F \& Brunetti P (1998). Pancreatic islet graft immunoisolation in alginate/polyaminoacidic (AG/PA) minimal microcapsules (MVCs'). The Transplantation Society XVII World Congress, Montreal, Canada, J uly 12-17. Book of Abstracts, 117.

55. Mares-Guia M \& Ricordi C (1997). Novel hetero-polysaccharide conjugates, novel S-INP polysaccharide gels and methods of making and using the same. United States Patent and Trademark Office Application for Letters and Patents. J une 17 (Patent No. 540519-2004.1). 